\title{
Structural Equation Modelling of Factors Influencing Users' Adoption of Smart Board: A South African University Perspective
}

\author{
Xolile Zincume and Mudaray Marimuthu
}

\begin{abstract}
Information and communication technologies (ICTs) have grown rapidly, becoming an integral part of today's society and affecting how daily activities are conducted worldwide. They have transformed the education landscape and today's classrooms have evolved from traditional blackboards to whiteboards and then to smart boards. The smart board technology (SBT) is considered one of the innovative teaching and learning technologies for different levels in education. However, the challenge is the low adoption of the SBT in teaching and learning environments by educators, particularly in Higher Education Institutions (HEIs). Therefore, the purpose of this study was to explore factors affecting the adoption of smart board technology. Using an extended Unified Theory of Acceptance and Use of Technology (UTAUT) model, a quantitative, cross-sectional survey was utilised to gather data from 224 academics from a South African university. Findings revealed that the adoption of smart board technology at the university is low and smart board features are inadequately used. Additionally, results showed that social influence and attitude toward using technology were significantly the key factors affecting users' intentions to adopt smart boards. Facilitating conditions had a very strong statistically significant effect on users' behaviour to use smart boards.
\end{abstract}

Index Terms-Higher education institutions, information and communication technology, smart board technology, unified theory of acceptance and use of technology.

\section{INTRODUCTION}

Technology has revolutionised traditional ways of doing things, and the education sector has not been immune to this revolution. Technology has transformed the education landscape, for example, today's classrooms are no longer restricted to the era of 'chalk' and 'talk'. Technology has brought innovative ways of transferring knowledge in the teaching and learning environment. Today's classrooms have evolved; first from traditional blackboards to whiteboards then to smart boards and these changes have contributed to the way teaching is being conducted. The technology that has found its way to classrooms is the smart board (SBT), commonly known as interactive whiteboards. The SBT is described as large, touch-sensitive screens mostly mounted on walls or as a standalone [1], [2]. They require a connection between a projector, a computer and software installed to them [3], [4]. As part of the teaching aids, they allow

Manuscript received February 7, 2021; revised June 18, 2021.

Xolile Zincume is with Durban University of Technology, South Africa (e-mail: zincumex@dut.ac.za).

Mudaray Marimuthu is with University of KwaZulu-Natal, South Africa (e-mail: marimuthum@ukzn.ac.za). educators to operate them using a finger, a special pen, or a keyboard while in different angles in the classroom [1], [5]. Smart boards are considered as one of the innovative teaching and learning technologies for different levels in education [6]. They have formed an essential part of today's classroom [7].

Often leadership and decision-makers in education implement technologies and encourage educators to use them to enhance teaching and learning in the classrooms [8]. However, Hepp and Hinostroza et al. [9] stated that new educational technologies become decorative dust collectors or underutilised in many instances. The reason is that the vital stakeholder in technology use are educators, and they are unwilling to adopt these technologies [10]. Literature reveals that smart boards are a valuable asset for teaching and learning in current classrooms [11], [12]. Installed smart boards enable educators to have the freedom to use different resources to deliver course content, partly because of tools embedded in smart boards, which include highlighting, drawing, annotating text, hide and reveal content, zooming and resizing [13].

While many classrooms today use smart boards as teaching aids, their initial inception was for business use [11]. Previous studies show that smart boards have proliferated in education, particularly in primary and secondary schools [14], [15]. This rapid growth in primary and secondary schools resulted because governments in different parts of the globe invested financial resources to implement smart boards in schools. Literature reveals that the United Kingdom (UK) led the adoption revolution of smart boards, which was significantly funded by the government [4]. After that, many schools in other countries followed, such as those in Australia, South Africa, and Taiwan [12], [15].

\section{PURPOSE OF THE STUDY}

Technologies are seen as a solution due to their ability to empower, increase access to education, respect different learning styles, improve quality of education and enhance teaching and learning [16], [17]. One of any university's strategic goals and objectives is to offer quality teaching and learning to all its students. In light of this, leadership at the universities invested financial resources towards implementing smart boards to enhance teaching and learning experiences and provide quality education to their students. For educational technology to enhance teaching and learning experiences, it must be adopted in the classroom. Educators are the key stakeholders to its successful adoption. Unless educators utilise smart boards in classrooms, this 
considerable investment will not be financially and pedagogically realised. Therefore, educators are the driving force behind the successful adoption of smart boards. SBTs are not transformational tools on their own but need creative educators who use them efficiently to benefit teaching and the learning environment [18], [19]. Korkmaz and Cakil [20] found that although educators felt that smart boards are useful, they were not used adequately. Further, Al-Faki and Khamis [21] suggested that educators are using smart boards predominantly as a presentation device only.

Since the implementation of smart boards, most research focused on the benefits of the smart board in education. However, limited studies focused on the adoption level and the factors affecting the adoption of smart boards. Since this study was undertaken in a developing country where resources are limited, it is imperative to determine factors affecting educators' adoption of smart boards in higher education institutions to increase the likelihood of success in these investments. This will make ICT policy implementers aware of the factors that will increase the level of adoption. Furthermore, few studies [15], [22] have been conducted in HEIs on the adoption of smart boards and much attention has been focused on its adoption in primary and secondary school levels [15]. Using a UTAUT model, this study investigated smart board adoption at a South African university. The study sought to answer the following questions:

1) What is the level of smart board adoption at a South African university?

2) Which are the commonly used features by smart board adopters?

3) What are the factors affecting the adoption of the SBT by academics at an HEI?

\section{LITERATURE REVIEW}

Effective use of ICTs facilitates the advocacy of student-centred teaching approaches that improve the quality of education [23]. Technology, such as smart boards, brings the best technology within the traditional 'brick and mortar' classroom. Some have named the smart board a 'digital hub' because of its ability to combine digital content such as text, pictures, videos, and the Internet in one board [18]. Stoica et al. [24] measured teachers' use of smart boards in teaching physics. They reported that smart boards created interest in the content because of using diverse media and real-time web content that resulted in students being motivated. Another feature of the SBT is that content can be easily recalled, hidden, browsed back and forth just by pen or hand movement [25]. This feature helps educators emphasise points and refer back to content already covered, linking new and old material, thereby connecting students to the entire course content. In so doing, students can easily pick up valuable points and easily remember concepts learnt as the features grant them the opportunity to move back and forth to images with features working much like a traditional flipchart [26]. The erasure feature makes it easy to edit written work, as one can easily rub off and edit work and even save it afterwards [27]. Smart boards are beneficial because they improve students' engagement [4], [15], increase motivation [28], increase student achievement and retention of information [28], [29], address different learning styles [30], enable collaboration [31] and provide a dynamic learning experience [32], [33], thereby improving teaching and learning experiences [34]. Lessons conducted using smart boards are fun and enjoyable [35], [36].

Smart board technologies have grown tremendously in the education environment globally and have become an integral part of teaching and learning. The widespread adoption of smart boards has been more visible in primary and secondary schools. A report revealed that, worldwide, smart board usage is high at primary and secondary schools at $45 \%$ and $44 \%$, respectively [37]. This indicates an increase of smart boards in schools which appears to be fuelled by funding provided by national governments to encourage the use of ICTs in schools and to enhance the education system [5]. The motivation behind the smart board investment originally came from empirical studies revealing that smart boards support interactive whole-class teaching and learning to enhance quality teaching [5], [13].

Al-Qirim [38] conducted a study to determine the use of smart boards in an HEI in Australia. Findings indicate that the usage of smart boards were high but this was mainly because the regulations to use smart boards in the institution were mandatory since there was a lack of alternate technologies in classes except for smart boards. Findings also indicated that educators had positive attitudes toward the use of smart boards.

A cross-nation study, conducted at six universities in South Africa, China, Mexico and the UK reported that for both teachers and students, lessons were more enjoyable, fun and the pace in the classroom was increased, enabling students to cover the course content quicker. Furthermore, students' concentration and understanding of lessons became better when smart boards were used in lessons [35]. Similarly, Agbatogun [39] evaluated the use of digital technologies in Southwest universities in Nigeria, where 492 lecturers were surveyed. Findings showed a low level of smart board adoption, meaning Nigerian universities were still to adopt and integrate smart boards in their teaching and learning environment.

Combrinck, Spamer and van Zyl [22] conducted a study in South Africa to assess students' perceptions of the use of smart boards and reported that $62 \%$ were in favour of lectures delivered using smart boards because they stimulate learning. Moreover, the same study stated that lecturers' ability to incorporate video clips and Internet links when teaching using smart boards lead to quality discussions and successful lectures.

\section{RESEARCH MODEL AND HyPOTHESES}

This study extended the UTAUT model to address this study's main objective to explore factors affecting the adoption of SBT by academics. Measures were taken from the study by Venkatesh and Morris et al. [40] and were modified to suit this study. The proposed conceptual model in this study maintained four constructs from UTAUT and added attitude toward using technology (ATUT) as a new construct. 


\section{A. Performance Expectancy (PE)}

In this study, PE refers to academics' beliefs that using the SBT will help them attain achievements in the teaching and learning environment. The UTAUT suggests that PE is the strongest predictor of intentions to use a technology [40]. Recent studies of technology adoption in education have highlighted the importance of PE in individuals' adoption of new technology. For example, Wong, Teo and Goh [41] assessed student teachers' intentions to use interactive whiteboards. PE was found to be the most substantial determining factor of behavioural intentions to adopt the technology.

Similarly, Lewis and Fretwell et al. [42] evaluated educators' use of established and emerging technologies in higher education and found that PE positively affected intentions to use technology. A study in Malaysian schools also found PE to significantly influence behavioural intention in the adoption of smart boards [43]. Based on the reviewed literature, the following hypothesis is suggested:

H1: Performance expectancy (PE) has a significant effect on the behavioural intentions of users to use smart boards.

\section{B. Effort Expectancy (EE)}

In this study, EE refers to the academics' beliefs that the use of a smart board will be without any technical and software-related challenges. Venkatesh et al. [40] theorised that effort expectancy affects behavioural intentions. Previous studies have reported opposing findings regarding the effect of effort expectancy on behavioural intentions. For example, some studies reported that EE significantly affected intentions to use technology [44], [45]. However, other studies found no direct effect between effort expectancy and behavioural intention [42]. It is therefore hypothesised that:

H2: Effort expectancy (EE) significantly affects the behavioural intentions of users to use smart boards.

\section{Social Influence (SI)}

The SI construct deals with academics' beliefs that the university and "other valuable people" (colleagues and friends) would influence their use of smart boards. The UTAUT postulates that social influence significantly affects individuals' intentions to adopt technology [40]. The finding of [42] shows that SI positively affects intentions to adopt technology, while previous studies revealed that SI remains the most significant construct affecting individuals' intention to adopt technology [44], [46]. Therefore, this study proposes the following hypothesis:

H3: Social influence (SI) has a significant effect on the behavioural intention of users to use smart boards.

\section{Facilitating Conditions (FC)}

In this study, FC refers to academics' belief that infrastructure (facilities and support) is available in the university to support smart board use in the teaching and learning environment. According to the UTAUT, FC has no direct effect on intentions to adopt new technology, but they significantly affect the actual behaviour to adopt new technology [40]. Technology adoption studies confirmed that facilitating conditions do not affect people's intentions to adopt new technology [44], [40]. Several other studies on technology adoption revealed that facilitating conditions significantly affect an individual's use behaviour to adopt technology [40], [47]. Raman et al. [43] and Šumak and Sorgo [48] found FC to significantly influence behavioural intention in the adoption of smart boards. The study, therefore, proposes the following hypothesis:

$\mathrm{H} 4$ : Facilitating conditions have a significant effect on users' behaviour to use smart boards.

\section{E. Attitude toward Using Technology (ATUT)}

Attitude toward using technology comes from the Theory of reasoned action (TRA). The TRA postulates that a person's attitude toward using technology positively affects behaviour intentions to adopt the technology [49]. Attitude toward using technology is the extent to which a person has a positive or negative perception towards a particular behaviour [50]. For example, when a person has a positive attitude towards a given technology, there is a high possibility that they will use that technology. Technology adoption studies have shown that attitude toward using technology significantly affects intentions to adopt the technology. A study by [51]_conducted to assess university faculty members' decision to adopt Web 2.0 found that attitudes strongly affected intentions to adopt Web 2.0 tools.

Similarly, El-Gayar and Moran [52] evaluated the adoption of Tablet-PC and found that attitude towards Tablet-PC significantly affected students' intentions. Studies by [29], [34] also indicated the students had a positive attitude to smart board usage. Thus, the following hypothesis is proposed:

H5: Attitude toward using technology (ATUT) has a significant effect on the behavioural intention of users to use smart boards.

\section{F. Behavioural Intention (BI) and Use Behaviour}

Behavioural intention refers to a person's willingness to perform a particular behaviour [49]. The UTAUT postulates that behavioural intention significantly affects individuals' behaviour to use new technology [40]. Studies on technology adoption revealed that behavioural intention was a dominating factor predicting people's behaviour to use technology. A recent study conducted in the UK, assessing teachers' acceptance and use of interactive whiteboards, found that behavioural intention significantly affected teachers' usage behaviour [47]. Thus, the following hypothesis is proposed:

H6: Behavioural intention (BI) has a significant effect on the behaviour of users to use a smart board.

Fig. 1 illustrates this study's proposed model.

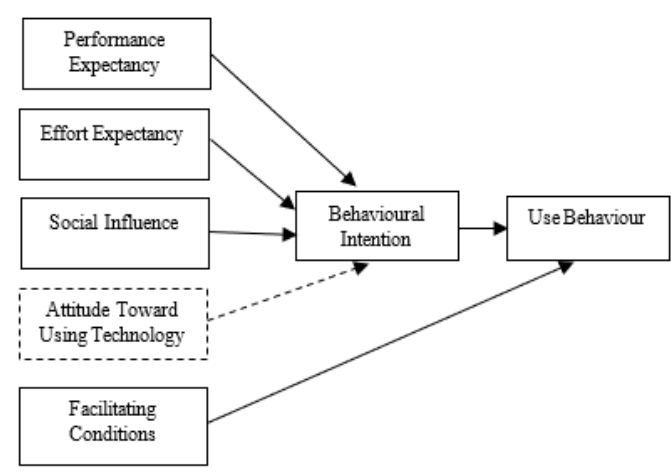

Fig. 1. Proposed research model adapted from [40] 


\section{RESEARCH Methodology}

Quantitative research was considered suitable for this study because it enabled data gathering from many academics dispersed on different campuses. Moreover, factors affecting adoption had been established in previous studies. Hence, this study wanted to measure these factors empirically within the context of SBT adoption in higher education in a South African context. The questionnaire for this study used items validated in the UTAUT study, including the measurement scales from the UTAUT model. The survey was designed using an online survey tool known as Google docs. The study site comprised different campuses of a South African university. This site was chosen due to the implementation of smart boards in their lecture venues. The population in this study is the academic personnel from this South African university. Academics in this study are the teaching faculty which refers to specialist instructors/junior lecturers, lecturers, senior lecturers, associate professors and professors.

To generalise to the entire academic staff population, this study used the probability sampling technique, simple random sampling. Simple random sampling uses a computer or random number tables to select a sample from a sampling frame [53]. This sampling technique allowed the researchers to choose a representative sample of academics and reduce any form of biases. In this way, each academic staff was granted an equal opportunity to participate in this study. An up-to-date list (sampling frame), consisting of academics' details was obtained from the university's Information Technology Support Services (ITSS). From this list, a sample was drawn. Using Microsoft Excel, random numbers were generated using a random formula. Each random number was associated with each academic personnel member. Following the guideline of [54], if the population size is 571, then 242 respondents should be selected, based on the $95 \%$ confidence level and $5 \%$ error. However, to increase the validity of data results, 350 random numbers associated with each academic staff member were selected to participate in the study.

Emails were sent to 350 academic staff members inviting them to participate in the online survey. Emails introduced the researchers, title of the study, the time required to complete a confidential and anonymous survey with a clear explanation. For further details on the study, academic staff members were referred to a Web link where the consent letter and questionnaire were to be found. Of the 350 surveys that were administered, 224 surveys were completed and returned. This constitutes a $64 \%$ response rate, which is an acceptable response rate for online surveys [55]. Data collected from the survey were analysed using the Statistical Package for the Social Sciences (SPSS) version 21. This was used for descriptive statistics addressing this study's research objectives (RQ1 and RQ2). To address RQ3, SEM-PLS from SmartPLS 2.0 software was used to analyse the hypothesised relationships between dependent and independent constructs.

\section{FINDINGS AND DISCUSSION}

\section{A. To what Extent do Academics Adopt SBT in the Teaching and Learning Environment?}

Research Question 1 (RQ1) aimed to establish the adoption levels of smart boards by academic staff. This question enabled the researchers to gain an insight into the number of academic staff who use or do not use smart boards. Fig. 2 exhibits the overall adoption levels of smart boards. More than half $(59 \%)$ of the respondents had never used smart boards before in their teaching environment. The remainder $(41 \%)$ of the study respondents were using smart boards in their teaching environment.

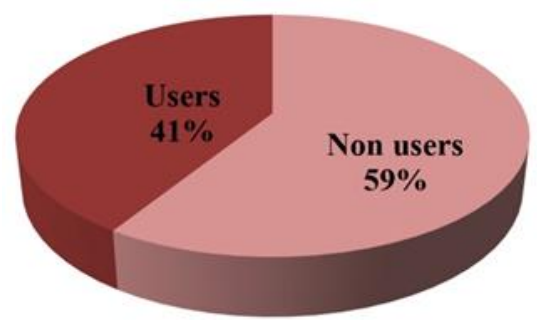

Fig. 2. Overall levels of smart board technology adoption.

This result shows that there are more non-users than users of the smart board. Therefore, it can be concluded that the adoption of smart boards at the university is low. This finding is congruent with findings by [39].

\section{B. What Are the Most Used Features of SBT by Academics in the Teaching and Learning Environment?}

Research Question 2 (RQ2) was to establish which smart board features were used by academics in their teaching environment. Therefore, this question was only answered by respondents who indicated that they were smart board users (number of participants $N=92$ ). Table I below shows the frequency of use of smart board features. The result reveals that the majority of academics had varying levels of responses from never, seldom, sometimes, often to always for nine smart board usage features. It is however evident that some smart board features are more preferred or used than others.

Results show a list of smart board features in ranking order from the most used to the least used, based on always and often on the Likert scale. According to Table I, the highest on the list of most used features is "as a projecting device", with $45 \%$ of academic staff always using this feature and $35 \%$ often using it. On the contrary, the least used smart board feature is "lesson recording", with $1 \%$ of academics always using this feature and $8 \%$ often using it. This could be a result of the complexity of using the lesson recording feature.

Given these results, it can be concluded that academics using smart boards are not adequately using all its features. The majority of respondents chose never, seldom and sometimes when asked how frequently they used smart board features. This finding is consistent with the findings of Sad and ÖZhan [56] and Bakadam and Asiri [14] that revealed that valuable features of smart board technology were underutilised. Instead, the smart board was mainly used as an overhead projector.

\section{What Are the Factors Affecting the Adoption of the SBT by Academics at an HEI?}

The results presented in this section are specifically for those who were identified as adopters of smart boards from this study's survey. The measurement models and structural model assessment were conducted in this section for adopters. 
The evaluations were conducted to test factors affecting the adoption of SBT by academics.

TABLE I: FREQUENCY OF SMART BOARD FEATURES’ USAGE RANKING

\begin{tabular}{|c|c|c|c|c|c|c|c|}
\hline Feature & Never & Seldom & Sometimes & Often & Always & Mean & Std. Dev \\
\hline As a projecting device & $5 \%$ & $5 \%$ & $10 \%$ & $35 \%$ & $45 \%$ & 4.08 & 1.12 \\
\hline Internet & $33 \%$ & $14 \%$ & $20 \%$ & $21 \%$ & $13 \%$ & 2.67 & 1.45 \\
\hline Digital pen & $36 \%$ & $25 \%$ & $13 \%$ & $18 \%$ & $8 \%$ & 2.37 & 1.34 \\
\hline Touchable screen & $32 \%$ & $21 \%$ & $24 \%$ & $16 \%$ & $8 \%$ & 2.48 & 1.30 \\
\hline Import picture, video, etc. & $36 \%$ & $20 \%$ & $22 \%$ & $16 \%$ & $7 \%$ & 2.38 & 1.30 \\
\hline Highlighter & $39 \%$ & $16 \%$ & $21 \%$ & $18 \%$ & $5 \%$ & 2.35 & 1.31 \\
\hline On-board/screen digital keyboard & $37 \%$ & $17 \%$ & $23 \%$ & $17 \%$ & $5 \%$ & 2.37 & 1.29 \\
\hline Digital eraser & $37 \%$ & $23 \%$ & $14 \%$ & $22 \%$ & $4 \%$ & 2.34 & 1.30 \\
\hline Lesson recording & $50 \%$ & $26 \%$ & $15 \%$ & $8 \%$ & $1 \%$ & 1.84 & 1.02 \\
\hline
\end{tabular}

TABLE II: FINAL CONFIRMATORY FACTOR ANALYSIS AND RELIABILITY ANALYSIS FOR USERS

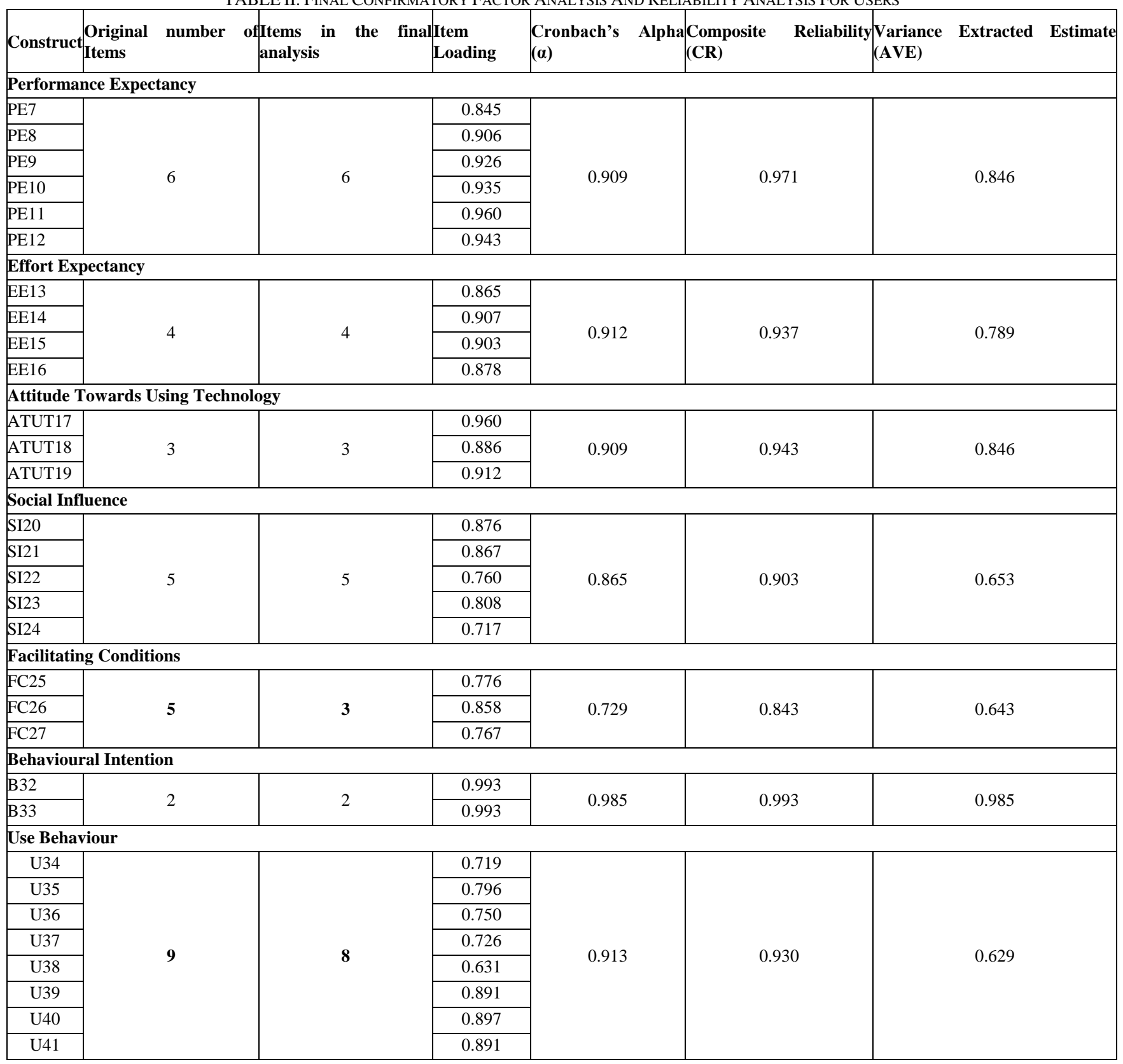

\section{1) Measurement model assessment (reliability and} validity)

This section presents the measurement model and structural model results for users of smart board. The evaluation of the measurement model's reliability, Cronbach's alpha and composite reliability were calculated.
An alpha value of 0.7 or higher is acceptable. Composite reliability for each factor should be above the 0.70 threshold [57]. Results in Table II below reflect the final scores after the three items with low loadings were deleted. Results exhibit that the composite reliability values of all constructs were greater than 0.70 , ranging from 0.870 to 0.960 and 
Cronbach's alpha values exceeded 0.7 , ranging from 0.769 to 0.950 for all constructs.

To verify construct validity, convergent and discriminant validity were assessed. For convergent validity, factor loading and average variance extracted (AVE) were evaluated. Convergent validity of scale items was evaluated in the following criteria: i) factor loading for all items should be above 0.50 benchmark [58] and ii) the AVE for each construct should be greater than 0.50 [59]. An assessment of factor loadings followed an iterative process. Following the recommendation of [59] two items (FC28 - "A specific person (or group) is available to assist when smart board problems of a technical nature arise" and FC29 - "Help is available to assist when smart board problems of an application nature arise") from the facilitating conditions construct and one item (U42 - "As a projecting device for presentations") from usage behaviour construct was dropped as a result of loadings less than 0.5 . Items that had loadings exceeding 0.5 were carried forward to the analysis. Table II exhibits reliability and validity analysis for the 92 respondents that use smart boards.

Table II demonstrates item loadings above 0.50 acceptable levels with a minimum item loading at 0.63 . Item loadings range from 0.63 to 0.993 . Thus, reliability and convergent validity are acceptable. This result suggests that discriminant validity could now be assessed. As per the guideline of Fishbein and Ajzen [59], discriminant validity was assessed using the analysis of AVE. The rule specifies that the AVE of each construct should be larger than all the other comparative constructs. Discriminate validity is considered adequate if the diagonal values of each construct are higher than the off-diagonal equivalent correlations of the other constructs.

Results in Table III above reveal that the diagonal AVE values (in bold) are larger than the off-diagonal columns and rows, thus demonstrating that they have discriminant validity. Having proven discriminant validity, the hypothesised relationships and significance of the structural model needed to be evaluated.

\section{2) Structural model analysis}

The structural model of adopters was assessed following a three-step process: i) path coefficients ( $\beta$ ); ii) path significance ( $p$-value); and iii) variance explained $\left(\mathrm{R}^{2}\right)$. The SmartPLS version 2.0 was used to validate the structural model for users. To determine each path coefficient, three hundred iterations (300) subsample, a default setting in PLS, were performed to estimate the theoretical model and hypothesised relationships. Thereafter, to test the significance of each path of the structural model in this study, the bootstrap procedure was performed. Bootstrap parameter settings were ninety-two (92) cases and five hundred (500) samples. The structural model in Fig. 3 displays five independent constructs (PE, EE, ATUT, SI and FC) and two dependent constructs, behavioural intention and use behaviour, which is also referred to as usage.

TABLE III: CONSTRUCT INTER-CORRELATION MATRIX — DISCRIMINANT VALIDITY

\begin{tabular}{|c|c|c|c|c|c|c|c|}
\hline CONSTRUCT & PE & EE & ATUT & SI & FC & BI & USE \\
\hline $\mathrm{PE}$ & 1.0 & & & & & & \\
\hline $\mathrm{EE}$ & 0.481 & 1.0 & & & & & \\
\hline ATUT & 0.773 & 0.526 & 1.0 & & & & \\
\hline $\mathrm{FC}$ & 0.490 & 0.720 & 0.483 & 0.443 & 1.0 & & \\
\hline $\mathrm{BI}$ & 0.517 & 0.410 & 0.634 & 0.638 & 0.432 & 1.0 & \\
\hline USAGE & 0.228 & 0.303 & 0.179 & -0.014 & 0.313 & -0.030 & 1.0 \\
\hline
\end{tabular}

\section{3) Structural model explanatory power}

The explanatory power $\left(\mathrm{R}^{2}\right)$ of the structural model was computed for both behavioural intention and usage. The results demonstrate that behavioural intentions have an $\mathrm{R}^{2}=$ 0.518. The independent constructs, attitude toward the use of technology and social influence collectively explained $51.8 \%$ of the variance in behavioural intentions of users to use smart boards. Therefore, the model is statistically significant if $\mathrm{p}<.0005$. This result indicates that the model fit is at an acceptable level for behavioural intentions $\left(R^{2}=51.8 \%\right)$. On the other hand, the explanatory power of use behaviour reveals that the $\mathrm{R}$-square of the model is 0.132 . In addition, the result demonstrates that the construct for facilitating conditions explained a significant proportion of the variance $13.2 \%$ of use behaviour. FC was the only significant predictor of use behaviour. However, the explanatory power of the structural model for use behaviour $R^{2}=13.2 \%$ is weak. This finding of low R-squared for use behaviour is not unique to this study; several studies have reached the same conclusion. For example, the low variance of use behaviour is consistent with $R^{2}=11 \%$ [60] and $R^{2}=16 \%$ [61].

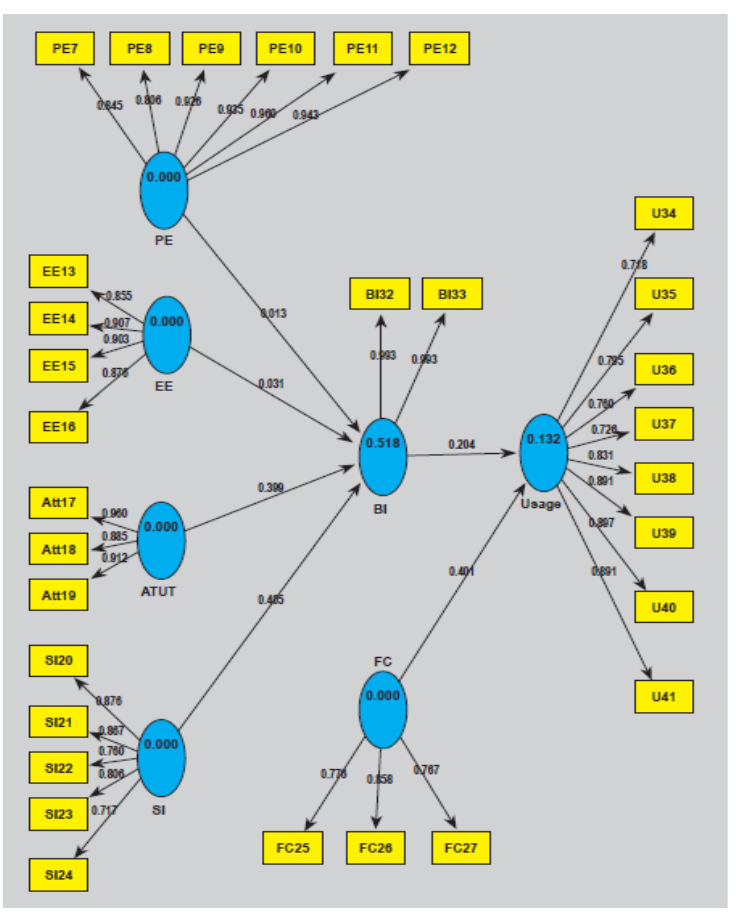

Fig. 3. Structural model estimates for users. 


\section{4) Path coefficient significance}

Six hypothesised relationships were evaluated for the users' structural model and summarised results are reflected in Table IV.

H1 - Performance expectancy (PE) has a significant effect on the behavioural intentions of users to use smart boards. This result shows that PE has no significant effect on users' intentions to use smart boards, $(\beta=-0.013, t=0.1449 p>$ 0.05). Thus, hypothesis $\mathrm{H} 1$ is not supported. This result contradicts the finding of [62].

H2 - Effort expectancy (EE) significantly affects the behavioural intentions of users to use smart boards. The results indicate that $\mathrm{EE}$ has no significant effect on users' intentions to use smart boards $(\beta=0.031, t=0.3595, p>0.05)$. Therefore, $\mathrm{H} 2$ is not supported. This result is conflicting with Wong, Teo and Russo [12] who revealed that EE positively affected student teachers' intentions to use IWBs. However, this finding could result from effort expectancy becoming insignificant after extended periods of technology usage [40].

H3 - Social Influence (SI) has a significant effect on the behavioural intention of users to use smart boards. Results reflect that SI has a significantly strong effect on users' intentions to use smart boards $(\beta=0.406, t=4.9523, p<$ $0.001)$. Consequently, hypothesis H3 is supported. SI has the most significant effect on the behavioural intentions of users to use smart boards. The finding of Chiyangwa and Alexander [63] supports this finding.

H4 - Facilitating conditions (FC) have a significant effect on the use behaviour of users to use smart boards. The results demonstrate that FC significantly affect use behaviour of smart board users $(\beta=0.406, t=3.9383, p<0.001)$. As a result, $\mathrm{H} 4$ is supported. This result is similar to the finding of [47], which revealed that facilitating conditions positively affect individuals' behaviour to use technology.

H5 - Attitude toward using technology (ATUT) has a significant effect on the behavioural intention of users to use smart boards. Results show that ATUT has a very significant statistical effect on users' intentions to use smart boards in their classrooms $(\beta=0.399,3.7373, p<0.001)$. Therefore, H5 is supported. This finding agrees with the findings of [60] which showed that attitude towards using technology significantly affected intentions.

H6 - Behavioural intention (BI) has a significant effect on the use behaviour of users to use smart boards. The construct for behavioural intention had no significant effect on users' behaviour to use smart boards in the teaching and learning environment $(\beta=-0.204,1.8678, p>0.05)$. Thus, the hypothesised relationship between $\mathrm{BI}$ and usage behaviour (H6) is not supported. This finding opposes the finding of Tosuntas, Karadağ and Orhan [47], Venkatesh and Morris et al. [40], which revealed that behavioural intentions positively affect behaviour to use technology.

Results illustrate that 3 of 6 hypothesised relationships were confirmed significant. Two factors, namely attitude toward the use of technology and social influence factors, were the predominant predictors of academics' intentions to use smart boards. The effort expectancy factor does not directly affect behavioural intention, whereas the performance expectancy factor negatively affects behavioural intentions to use smart boards. The factor for facilitating conditions was a strong determinant of academics' usage of smart boards. However, academics' intentions to use smart boards had no significant effect on use behaviour.

TABLE IV: SUMMARY OF USERS' STRUCTURAL MODEL AND HYPOTHESES RESULTS

\begin{tabular}{|l|l|l|l|l|}
\hline Hypothesis & Causal path & $\boldsymbol{t}$-test & $\boldsymbol{p}$-value & $\begin{array}{l}\text { Hypotheses } \\
\text { supported }\end{array}$ \\
\hline H1 & PE -> BI & 0.1449 & 0.8851 & No \\
\hline H2 & EE-> BI & 0.3595 & 0.7201 & No \\
\hline H3 & SI -> BI & 4.9523 & $\begin{array}{l}0.0001^{* *} \\
*\end{array}$ & Yes \\
\hline H4 & FC-> USAGE & 3.9383 & $\begin{array}{l}0.0002^{* *} \\
*\end{array}$ & Yes \\
\hline H5 & ATUT-> BI & 3.7373 & $\begin{array}{l}0.0003^{* *} \\
*\end{array}$ & Yes \\
\hline H6 & BI->USAGE & 1.8678 & 0.0650 & No \\
\hline
\end{tabular}

\section{RECOMMENDATIONS}

\section{A. To What Extent do Academics Adopt SBT in the Teaching and Learning Environment?}

Descriptive analysis revealed that smart board adoption level is low, with only $41 \%$ of respondents indicating that they use smart boards in their teaching environment. This finding suggests that the uptake of smart boards is slow, and academics might still be adapting to this change which is generally not easy. This is because there is resistance in the early stages of change, and adapting to change is a development process that does not happen overnight. The finding has implications for students, management and decision-makers. For students, it means that they are denied the opportunity to experience interactive teaching and learning, as literature revealed that the SBT enables interactive teaching, allowing students to experience technology inside a traditional classroom, thereby enhancing the learning experience.

For leadership and decision-makers, it questions the efforts made towards encouraging academics to buy into such a huge investment which was supposed to enhance course content delivery, collaboration and engagement in teaching and learning. Therefore, decision-makers and leaders must create policies guiding the use of smart boards as a tool of teaching and learning. These policies include smart board marketing strategies and educational workshops promoting smart boards, not just as a brand but as their value in enhancing pedagogy and quality of teaching and learning.

Thus, proper programmes, policies and suitable human resources and technical support should be in place to encourage the use of smart boards to enhance teaching and learning, leading to quality education that benefits both the academics and students.

\section{B. What Are the Most Used Features of SBT by Academics in the Teaching and Learning Environment?}

The results show that academics inadequately use smart board features because the majority of those using smart board technology are utilising the elementary features such as using it as a projecting device rather than exploiting the advanced features such as lesson recording. This finding suggests that academics are still in a 'supported didactic' stage in the adoption of smart board technology, because, in 
this stage, academics confine the SBT use to a presentation tool rather than exploring advanced features. Though this stage is likely at the very early phases of smart board implementation, a shift to a more student engaging stage is unavoidable because the 'supported didactic' stage is not suitable for students at HEIs that prefer a student-centred approach rather than a teacher-centred approach. This stage is also not suitable because, currently, HEIs globally advocate for student-centred approaches that propel the students to be lifelong learners.

The finding of inadequate use of smart boards could be attributed to two reasons. Firstly, academics indicated they are more familiar with previous technologies such as projectors which have been in the teaching environment for a long time. Thus, when they adopt smart boards, academics start with familiar features and then advance to the other features. Hence, results reflect that a small number of academics have moved to use the advanced features. Secondly, a feature like lesson recording is a complex and advanced feature of the SBT. Consequently, academics need exposure and training to familiarise themselves with advanced features of SBT to use it optimally.

Therefore, initial SBT and consistent training programmes and workshops should be in place. These training programmes and workshops will enable academics to be exposed to existing SBT features, functionality, and benefits in the teaching and learning environment, which is a necessity rather than an option. Furthermore, academics must be taught during workshops to align their course content with new SBT and ways to integrate it in the classroom. This should incorporate a support structure to assist them in redesigning, aligning and integrating their course content in the classroom. In this way, smart board adoption has a high likelihood to improve and its features used effectively to benefit both the academics and students, thereby enhancing the quality of teaching and learning.

\section{What Are the Factors Affecting the Adoption of Smart Board Technology in a Higher Education Institution?}

The social influence factor had the strongest effect on users' intentions to use smart boards. This implies that when academic management members, academics' colleagues and other important people recommend that academics use smart boards, they increase their intentions to use them. Thus, management should consider having structures to clearly and explicitly communicate their vision about the implemented technology to their staff to use technology. This may be achieved through technological communication means, clear policies and visible support structures.

Similarly, attitude toward using technology had a significant effect on user's intentions to use smart boards. This means that, when academics are motivated to use smart boards, their attitudes toward using them will increase and thereby enhance their intentions to use smart boards. Management should have a policy or a reward programme that recognises academics who are early adopters of technology and reward them for being champions to motivate and support upcoming smart board users. Additionally, management should create a conducive environment to provide rewards and support and promote research endeavours on the newly implemented technology, thereby increasing the understanding, importance, and benefits of the technology in education.

Results also demonstrated that the facilitating conditions construct was a key factor affecting the adoption of smart boards for users. This result denotes that when the users' group is provided with sufficient infrastructure, human and technical resources, their use of smart boards will be improved substantially. To improve current levels of smart board adoption, it is necessary to address facilitating conditions since it is one of the most important factors affecting the actual use of smart boards. This implies that HEIs already using smart boards must provide adequate institutional resources, training and support.

Therefore, to accomplish high adoption, HEIs intending to implement the SBT must consider these three factors to ensure that they are properly addressed before the implementation process begins. This means setting faculty programmes guiding marketing approaches that transcend beyond marketing the smart board as a technology or brand because it is not beneficial on its own. It is important to show academics the value of smart boards and their ability to improve their performance and the quality of teaching and learning.

Moreover, the marketing policies implemented must highlight the value to academics in the effective use of smart boards which must be done by management as they play an important role in increasing intentions to adopt technology. In this way, academics' attitudes will be increased, leading to increased intentions to use smart boards. If intentions are increased, there is an excellent likelihood that academics will use smart boards. Thus, monies invested in implementing smart boards will bear fruits for students, academic staff and the teaching and learning environment.

\section{FUTURE RESEARCH AND CONCLUSION}

Data were collected and analysed from academics from one university in South Africa. This finding cannot be generalised to other universities in South Africa. A larger sample size of academics from different universities will enable the generalisation of the results in HEIs in South Africa.

To further this study, a qualitative research could be used to establish additional factors affecting adoption, which can then be measured using a quantitative research approach to target a larger population. Future studies can expand the study to incorporate students' attitudes towards smart board use in teaching and learning. Furthermore, studies could incorporate the moderating factors to measure their effect on the independent and dependent factors and their effect on the variance explained in behavioural intentions and use behaviour of academics.

In conclusion, the successful and effective adoption of smart boards has little to do with implementing them in lecture rooms. Rather, for the successful adoption of smart boards, HEIs need to consider important factors such as social factors (marketing strategies and management practices), facilitating conditions (sufficient and functional resources, i.e., uninterrupted Internet access, uninterrupted 
power supply, hardware and software and installation of new technology to all lecture venues), and adequate and continuous technical and pedagogical training and support. Management and decision-makers in HEIs should address these factors as inhibitors of technology adoption to increase adoption, thereby enhancing lecturers and students teaching and learning experiences, resulting in improved quality of education.

\section{CONFLICT OF INTEREST}

The authors declare no conflict of interest.

\section{AUTHOR CONTRIBUTIONS}

Xolile conducted the research and analyzed the data; Xolile and Mudaray wrote the paper; all authors had approved the final version

\section{REFERENCES}

[1] R. Marzano, "The art and science of teaching," Educational Leadership, vol. 69, no. 1, pp. 86-87, 2011.

[2] E. Willems and J. Willems, "Interactive white (board) elephants: A case of change mismanagement," presented at the ASCILITE-Australian Society for Computers in Learning in Tertiary Education Annual Conference, 2011.

[3] N. Al-Qirim, A. Mesmari, K. Mazroeei, S. Khatri, and Z. Kaabi, "Developing teaching scenarios in the classroom using interactive smart board ecosystem," presented at the 4th IEEE International Conference on Digital Ecosystems and Technologies (DEST), April 13, 2010, pp. 525-530.

[4] S. Bennett and L. Lockyer, "A study of teachers' integration of interactive whiteboards into four Australian primary school classrooms," Learning, Media and Technology, vol. 33, no. 4, pp. 289-300, 2008.

[5] V. Armstrong, S. Barnes, R. Sutherland, S. Curran, S. Mills, and I. Thompson, "Collaborative research methodology for investigating teaching and learning: The use of interactive whiteboard technology," Educational Review, vol. 57, no. 4, pp. 457-469, 2005.

[6] Y. K. Türel and T. E. Johnson, "Teachers' belief and use of interactive whiteboards for teaching and learning," Educational Technology \& Society, vol. 15, no. 1, pp. 381-394, 2012.

[7] M. Jwaifell and A. M. Gasaymeh, "Using the diffusion of innovation theory to explain the degree of english teachers' adoption of interactive whiteboards in the modern systems school in Jordan: A case study," Contemporary Educational Technology, vol. 4, no. 2, pp. 138-149, 2013.

[8] B. Pynoo, J. Tondeur, J. Van Braak, W. Duyck, B. Sijnave, and P. Duyck, "Assessing teachers' acceptance of educational technologies: Beware for the congruency between user acceptance and actual use," presented at the 19th International Conference on Computers in Education (ICCE), 2011.

[9] P. K. Hepp, E. S. Hinostroza, E. M. Laval, and L. F. Rehbein, "Technology in schools: Education, ICT and the knowledge society," Washington, DC: World Bank, Distance \& Open Learning and ICT in Education Thematic Group, Human Development Network, Education, pp. 30-47, 2004.

[10] J. Mueller, E. Wood, T. Willoughby, C. Ross, and J. Specht, "Identifying discriminating variables between teachers who fully integrate computers and teachers with limited integration," Computers \& Education, vol. 51, no. 4, pp. 1523-1537, 2008.

[11] T. Aytaç, "Interactive whiteboard factor in education: Students points of view and their problems," Educational Research and Reviews, vol. 8 no. 20, pp. 1907-1915, 2013.

[12] K. T. Wong, T. Teo, and S. Russo, "Interactive whiteboard acceptance: Applicability of the UTAUT model to student teachers," The Asia-Pacific Education Researcher, vol. 22, no. 1, pp. 1-10, 2013.

[13] S. Hennessy and L. London, "Learning from international experiences with interactive whiteboards: The role of professional development in integrating the technology," OECD Education Working Paper, vol. 89, pp. 1-32, 2013.

[14] E. Bakadam and M. J. S. Asiri, "Teachers' perceptions regarding the benefits of using the interactive whiteboard (IWB): The case of a Saudi intermediate school," Procedia-Social and Behavioral Sciences, vol. 64, pp. 179-185, 2012.

[15] H. Slay, I. Siebörger, and C. Hodgkinson-Williams, "Interactive whiteboards: Real beauty or just lipstick?" Computers \& Education, vol. 51, no. 3, pp. 1321-1341, 2008.

[16] T. J. Brigham, "Smart boards: A reemerging technology," Medical Reference Services Quarterly, vol. 32, no. 2, pp. 194-202, 2013.

[17] G. B. Gudmundsdottir, "When does ICT support education in South Africa? The importance of teachers' capabilities and the relevance of language," Information Technology for Development, vol. 16, no. 3, pp. 174-190, 2010.

[18] C. Betcher and M. Lee, The Interactive Whiteboard Revolution: Teaching with IWBs: Aust Council for Ed Research, 2009.

[19] S. Kennewell and G. Beauchamp, "The features of interactive whiteboards and their influence on learning," Learning, Media and Technology, vol. 32, no. 3, pp. 227-241, 2007.

[20] O. Korkmaz and I. Cakil, "Teachers' difficulties about using smart boards," Procedia-Social and Behavioral Sciences, vol. 83, pp. 595-599, 2013.

[21] I. M. Al-Faki and A. H. A. Khamis, "Difficulties facing teachers in using interactive whiteboards in their classes," American International Journal of Social Science, vol. 3 no. 2, pp. 137-158, 2014.

[22] M. Combrinck, E. Spamer, and M. Zyl, "Students' perceptions for the use of interactive white boards in the delivery of distance learning programmes," presented at the International Conference on Communication, Media, Technology and Design, Istanbul, Turkey, 2014.

[23] P. Achimugu, O. Oluwagbemi, and A. Oluwaranti, "An evaluation of the impact of ICT diffusion in Nigeria's higher educational institutions," Journal of Information Technology Impact, vol. 10, no. 1, pp. 25-34, 2010.

[24] D. Stoica, F. Paragina, S. Paragina, C. Miron, and A. Jipa, "The interactive whiteboard and the instructional design in teaching physics," Procedia-Social and Behavioral Sciences, vol. 15, pp. 3316-3321, 2011.

[25] P. Knight, J. Pennant, and J. Piggott, "The power of the interactive whiteboard," Micromath, vol. 21, no. 2, pp. 11-15, 2005.

[26] N. Mercer, S. Hennessy, and P. Warwick, "Using interactive whiteboards to orchestrate classroom dialogue," Technology, Pedagogy and Education, vol. 19, pp. 195-209, 2010.

[27] J. Browne, B. Lee, S. Carpendale, N. Riche, and T. Sherwood, "Data analysis on interactive whiteboards through sketch-based interaction," Proceedings of the ACM International Conference on Interactive Tabletops and Surfaces, pp. 154-157, 2011.

[28] F. Biçak, "Investigation of the views of teachers toward the use of smart boards in the teaching and learning process," Journal of Pedagogical Research, vol. 3, no. 1, pp. 15-23, 2019.

[29] I. Ü. Yapici and F. Karakoyun, "High school students' attitudes towards smart board use in biology classes," Educational Research and Reviews, vol. 11, no. 7, pp. 459-465, 2016.

[30] O. Hacifazlioglu, O. A. Sacli, and I. Yengin, "Lecturers' attitudes towards the use of technology: Alternative strategies for faculty administrators," 2007.

[31] H. J. Lai, "Secondary school teachers' perceptions of interactive whiteboard training workshops: A case study from Taiwan," Australasian Journal of Educational Technology, vol. 26, no. 4, pp. 511-522, 2010.

[32] M. Z. Bidaki and N. Mobasheri, "Teachers' views of the effects of the interactive white board (IWB) on teaching," Procedia-Social and Behavioral Sciences, vol. 83, no 0, pp. 140-144, 2013.

[33] S. H. Mun and A. H. Abdullah, "A review of the use of smart boards in education," in Proc. IEEE 8th International Conference on Engineering Education (ICEED), pp. 120-125, December 2016.

[34] O. Gurbuzturk, "Investigation of elementary education students' attitudes towards the use of smart boards," International Electronic Journal of Elementary Education, vol. 11, no. 1, pp. 55-61, 2018.

[35] J. Cuthell, "Tools for transformation: The impact of interactive whiteboards in a range of contexts," in Proc. Society for Information Technology \& Teacher Education International Conference 2006, pp. 1491-1497, Association for the Advancement of Computing in Education (AACE).

[36] A. Kirbas, "Student views on using smart boards in Turkish education," Universal Journal of Educational Research, vol. 6, no. 5, pp. 1040-1049, 2018.

[37] (2010). Future WhitePaper.pdf source consulting. Projector and Interactive Whiteboard Usage in Primary and Secondary Schools. [Online]. 
http://www.futuresourceconsulting.com/press/201005\%20Projector+I WB\%20

[38] N. Al-Qirim, "Smart board technology success in tertiary institutions: The case of the UAE University," Education and Information Technologies, vol. 21, no. 2, pp. 265-281, 2016.

[39] A. O. Agbatogun, "Interactive digital technologies' use in Southwest Nigerian universities," Educational Technology Research and Development, vol. 61, no. 2, pp. 333-357, 2013.

[40] V. Venkatesh, M. G. Morris, G. B. Davis, and F. D. Davis, "User acceptance of information technology: Toward a unified view," MIS Quarterly, vol. 27, no. 3, pp. 425-478, 2003.

[41] K. T. Wong, T. Teo, and P. S. C. Goh, "Understanding the intention to use interactive whiteboards: Model development and testing," Interactive Learning Environments, pp. 1-17, 2013.

[42] C. C. Lewis, C. E. Fretwell, J. Ryan, and J. B. Parham, "Faculty use of established and emerging technologies in higher education: A unified theory of acceptance and use of technology perspective," International Journal of Higher Education, vol. 2, no. 2, pp. 22, 2013.

[43] A. Raman, Y. Don, R. Khalid, F. Hussin, M. S. O. Fauzee, and M. Ghani, "Technology acceptance on smart board among teachers in terengganu using UTAUT model," Asian Social Science, vol. 10, pp. 84-91, 2014.

[44] M. R. M. Jaradat and M. S. Rababaa, "Assessing key factors that influence on the acceptance of mobile commerce based on modified UTAUT," International Journal of Business and Management, vol. 8, no. 23, pp. 102-112, 2013.

[45] V. Venkatesh, J. Y. Thong, and X. Xu, "Consumer acceptance and use of information technology: Extending the unified theory of acceptance and use of technology," MIS Quarterly, vol. 36, no. 1, pp. 157-178, 2012.

[46] C. S. Yu, "Factors affecting individuals to adopt mobile banking: Empirical evidence from the UTAUT model," Journal of Electronic Commerce Research, vol. 13, no. 2, pp. 104-121, 2012.

[47] Ş. B. Tosuntaş, E. Karadă̆, and S. Orhan, "The factors affecting acceptance and use of interactive whiteboard within the scope of FATIH project: A structural equation model based on the Unified Theory of acceptance and use of technology," Computers \& Education, vol. 81 , pp. 169-178, 2015 .

[48] B. Šumak and A. Sorgo, "The acceptance and use of interactive whiteboards among teachers: Differences in UTAUT determinants between pre- and post-adopters," Computers in Human Behavior, vol 64, pp. 602-620, 2016.

[49] M. Fishbein and I. Ajzen, Belief, Attitude, Intention and Behaviour: An Introduction to Theory and Research, Mass: Addison-Wesley Pub. Co, 1975.

[50] I. Ajzen, "The theory of planned behavior," Organisational Behavior and Human Decision Processes, vol. 50, no. 2, pp. 179-211, 1991.

[51] H. Ajjan and R. Hartshorne, "Investigating faculty decisions to adopt Web 2.0 technologies: Theory and empirical tests," The Internet and Higher Education, vol. 11, no. 2, pp. 71-80, 2008.

[52] O. F. El-Gayar and M. Moran, "College students' acceptance of tablet PCs: An application of the UTAUT model," Annual Meeting of the Decision Sciences Institute Conference Proceedings, pp. 2845-2850, 2006.

[53] M. Saunders, P. Lewis, and A. Thornhill, Research Methods for Business Students, 6th ed. London: Pearson, 2012.

[54] B. Johnson and L. Christensen, Educational Research: Quantitative, Qualitative and Mixed Approaches, 4th ed. United States of America: SAGE Publications Inc., 2012.
[55] A. Rubin and E. Babbie, Brooks/Cole Empowerment Series: Essential Research Methods for Social Work, 3rd ed. Cengage Learning, 2012.

[56] S. N. Şad and U. ÖZhan, "Honeymoon with IWBs: A qualitative insight in primary students' views on instruction with interactive whiteboard," Computers \& Education, vol. 59, no. 4, pp. 1184-1191, 2012.

[57] J. F. Hair, C. M. Ringle, and M. Sarstedt, "PLS_SEM: Indeed a silver bullet," Journal of Marketing Theory and Practice, vol. 19, no. 2, pp. 139-151, 2011.

[58] W. W. Chin, "The partial least squares approach to structural equation modelling," Modern Methods for Business Research, vol. 295, no. 2, pp. 295-336, 1998

[59] M. Fishbein and I. Ajzen, Belief, Attitude, Intention and Behaviour: An Introduction to Theory and Research, Mass: Addison-Wesley Pub. Co, 1975.

[60] M. Moran, M. Hawkes, and O. El Gayar, "Tablet personal computer integration in higher education: Applying the unified theory of acceptance and use technology model to understand supporting factors," Journal of Educational Computing Research, vol. 42, no. 1, pp. 79-101, 2010.

[61] H. Motaghian, A. Hassanzadeh and D. K. Moghadam, "Factors affecting university instructors' adoption of web-based learning systems: Case study of Iran," Computers \& Education, vol. 61, pp. 158-167, 2013.

[62] S. Nägle and L. Schmidt, "Computer acceptance of older adults," Work-Journal of Prevention Assessment and Rehabilitation, vol. 41, pp. 3541, 2012.

[63] T. B. Chiyangwa and P. M. Alexander, "Rapidly co-evolving technology adoption and diffusion models," Telematics and Informatics, vol. 33, no. 1, pp. 56-76, 2016.

Copyright (C) 2022 by the authors. This is an open access article distributed under the Creative Commons Attribution License which permits unrestricted use, distribution, and reproduction in any medium, provided the original work is properly cited (CC BY 4.0).

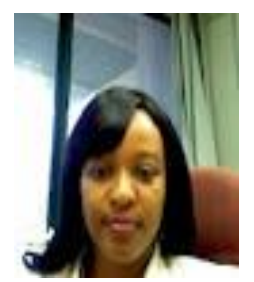

Xolile Zincume holds a master of commerce degree in information systems and technology obtained at the University of KwaZulu_Natal in the School of Management, Information Technology and Governance in Durban, South Africa. She is a lecturer in the Department of Information Systems at the Durban University of Technology. She lectures databases and information systems. Her research interests are teaching and learning technologies, smart farming, and internet of things.

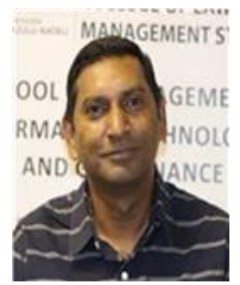

Mudaray Marimuthu is a lecturer in the School of Management, Information Technology and Governance at the University of KwaZulu-Natal. He currently lectures systems analysis and design, databases, programming and software engineering. His research interests are in e-commerce, information systems adoption and software development methodologies. 